\title{
Diet of Cnesterodon decemmaculatus (Poeciliidae) and Jenynsia multidentata (Anablepidae) in a hypertrophic shallow lake of Uruguay
}

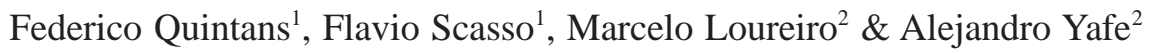 \\ 1. Limnology Section, Faculty of Sciences, Universidad de la República. Iguá, 4225, 11400 Montevideo, Uruguay. (cara@ fcien.edu.uy)
} 2. Vertebrates Section, Faculty of Sciences, Universidad de la República. Iguá, 4225, 11400 Montevideo, Uruguay.

\begin{abstract}
Diet of Cnesterodon decemmaculatus (Jenyns, 1842) and Jenynsia multidentata (Jenyns, 1842) were analysed in Lake Rodó, an urban hypertrophic lake from Montevideo, Uruguay. Both species displayed omnivory. The most consumed items for $C$. decemmaculatus were zooplankton, periphyton, phytoplankton and detritus; the diet of J. multidentata included zooplankton, insects, crustaceans and juvenile fish. Our results suggest that both species could be acting as facultative planktivores. The fish community of this lake is characterised by the dominance of $C$. decemmaculatus and J. multidentata. Under this condition, predation on large-bodied zooplankton could indirectly be contributing to maintain a high phytoplankton abundance and a low water transparency.
\end{abstract}

KEYWORDS. Fish feeding, facultative planktivores, eutrophication.

RESUMEN. Dieta de Cnesterodon decemmaculatus (Poeciliidae) y Jenynsia multidentata (Anablepidae) en un lago hipereutrófico de Uruguay. Se analizaron las dietas de Cnesterodon decemmaculatus (Jenyns, 1842) y Jenynsia multidentata (Jenyns, 1842) en el Lago Rodó, un lago urbano hipereutrófico de Montevideo, Uruguay. Ambas especies mostraron un comportamiento omnívoro. Los ítems más consumidos por C. decemmaculatus fueron zooplancton, perifiton, fitoplancton y detritos; la dieta de J. multidentata incluyó zooplancton, insectos, crustáceos y peces juveniles. Estos resultados sugieren que ambas especies pueden actuar como planctívoros facultativos. La comunidad de peces de este lago se caracteriza por la dominancia de C. decemmaculatus y J. multidentata. Bajo esta condición, la depredación sobre el zooplancton de gran tamaño podría indirectamente estar contribuyendo a una alta abundancia de fitoplancton y una baja transparencia del agua.

PALABRAS CLAVE. Alimentación de peces, planctívoros facultativos, eutrofización.

Fish play a key role in the structure of aquatic communities, exercising direct effects on their prey and indirect effects throughout the trophic web. The great diversity of feeding habits of neotropical fish means that they employ a wide range of energy sources including primary producers, primary and secondary consumers including other fish and detritus.

In eutrophic lakes, the ratio of piscivorous to planktivorous fish usually decreases, causing plankton community modifications and water quality changes, such as decrease in large zooplankton grazers, increase in phytoplankton and decrease in transparency (Johansson \& Persson, 1986; Persson et al., 1988). The classic linear food web (piscivores-planktivoreszooplankton-phytoplankton) described for temperate lakes and its cascading effects would be weakened when omnivory dominate the interactions in the neotropics (Lazzaro, 1997; Pinel-Alloul et al., 1998). Biomanipulation is an important tool for the restoration of eutrophic lakes. It has been based on the knowledge of trophic interactions in temperate lakes (Mc QueEN, 1990), but the role of top-down control in tropical and subtropical lakes is still poorly understood (LAZZARO, 1997). Thus, studies of the diet of neotropical freshwater fishes are a basic aspect to understand trophic web functioning and trophic groups dynamics, which may contribute to adequate environmental management programs.

In Lake Rodó, Cnesterodon decemmaculatus (Jenyns, 1842) is the dominant species, and together with Jenynsia multidentata (Jenyns, 1842), accounted for $98 \%$ of the fish biomass of the lake (Scasso et al., 2001). EsCALANTE (1983) found that $C$. decemmaculatus fed on algae and vegetal material, but this study was only based on the gut contents of 19 individuals of an Argentinean lake. With respect to J. multidentata diet, EsCALANTE (1983) found that amphipods were the main item followed by zooplankton and algae.

This work focussed on the diet of $C$. decemmaculatus and J. multidentata in this hypertrophic urban lake. Due to the wide distribution of both species in the Río de la Plata basin, and coastal basins of Southern Brazil, Uruguay and central Argentina (Rosa \& Costa, 1993; GHEDOTTI, 1998), the results of this study could have regional relevance to identify their main trophic relationships and to determine their potential cascading effects in eutrophic systems.

\section{MATERIAL AND METHODS}

Lake Rodó $\left(35^{\circ} 55^{\prime} \mathrm{S}, 56^{\circ} 10^{\prime} \mathrm{W}\right)$ is an artificial, subtropical hypertrophic system located on an urban park in Montevideo, Uruguay. The lake area is $1.3 \mathrm{ha}$, and the maximum depth is $2.4 \mathrm{~m}$. The eutrophic condition of the lake is associated with high nutrient loads from the urban area run-off and the groundwater supply. It is a turbid system with high algal biomass (SCASSO et al., 2001).

There were undertook six seasonal fish sampling between August 1999 and November 2000. Each sampling was performed early in the morning and during the sunset. Fish were captured from a boat by electrofishing in the whole lake, and preserved on ice while were carried to 
the laboratory. Sampled fishes were measured (total length, TL) and weighted; their guts were removed, weighted and fixed in 10\% formalin and the contents were analysed with a dissecting microscope. Because $C$. decemmaculatus does not have stomach, there were analysed the contents of all the digestive tract. A subsample of analyzed fishes were deposited in Colección de Peces de la Facultad de Ciencias: ZVC-P 3828, ZVC-P 4063, ZVC-P 4198, ZVC-P 5021 (Jenynsia multidentata), ZVC-P 3827 (Cnesterodon decemnmaculatus).

In order to investigate differences in the diet according to fish size, three body-size classes were defined; for $C$. decemmaculatus class I ( $<25 \mathrm{~mm})$, class II (25-35mm) and class III (>35 mm); for J. multidentata class I (<30mm), class II (30-40mm) and class III (>40mm).

The repletion degree (RI) of the digestive contents was calculated according to AlBERTINE-BerHaUt (1973), which employs a five discrete levels scale: 0 for empty, 1 for almost empty, 2 for semi empty, 3 for semi full and 4 for full, based on a relationship between the digestive tract and fish weights.

The Alimentary Importance Index (AII) (GRANADO \& GARCíA-Novo, 1986) was calculated as follows:

$\mathrm{IIA}=\Sigma(\mathrm{x} \cdot \mathrm{K}) / \mathrm{n}-1$

Where $\mathrm{x}$ is the numerical frequency diet (according to the frequency of occurrence method of HySLOP, 1980), and $\mathrm{K}$ is the proportion of the same item in the gut content (following the scale proposed by GuILLÉn \& GranAdo (1984): 0-absent, 1-scarce (less than $25 \%$ of the total content), 2-frequent (between 25 and $50 \%$ of the content), and 3 -abundant (more than 50\%)), proportionally to the total gut content. The $\mathrm{n}$ value expresses the number of categories (items). The index ranges from 0 to 1 , and values higher than 0.3 are considered to be principal food, between 0.15 and 0.3 additional food, and lower than 0.15 occasional food.

To quantify the similarity in the diet between species and among size classes of the same species, the feeding overlap (C) according the index simplified of Morisita modified by HoRn (1966) (KREBS, 1989):

$\mathrm{C}=2 \Sigma$ pi1 1 pi $/\left(\Sigma\right.$ pi $1^{2}+\Sigma$ pi $\left.2^{2}\right)$

where piland pi2 are the numerical proportion of the $\mathrm{i}$ item in the species 1 and 2 of all samplings respectively. This index also ranges from 0 to 1 , and when the value exceeds 0.6 it is considered to be biologically relevant overlap (ZARET \& RAND, 1971).

The results were compared with the non-parametric Mann-Whitney U test, and correlations were made by Spearman's rank correlation (ZAR, 1999); with $\alpha=0.05$ in every case.

\section{RESULTS}

A total of 278 individuals of $C$. decemmaculatus (10 - 45mm TL) and 259 individuals of J. multidentata (18 - 82mm TL) were examined. Nine and 24 food items were observed in the gut contents of $C$. decemmaculatus and J. multidentata respectively (Tab. I).

Cnesterodon decemmaculatus. In this species, $5.5 \%$ of the guts were empty. The comparison of means of the repletion degree between the morning (1.8) and the evening (2.4) samples, showed significant differences
$(\mathrm{U}=2257.5, \mathrm{p}<0.01)$. The mean repletion degree values of classes I, II, and III including all samplings, were 1.7, 1.9, and 2.7 respectively. Summer and winter 1999 samplings showed the lowest RI values, while spring 1999 and autumn 2000 showed higher RI values for all body size classes. The highest body size class showed the highest RI values during all samplings, and body size class II showed de second-higher RI values (Fig. 1), except for both spring samplings.

According to the frequency of occurrence, the most frequent food items were phytoplankton, detritus, periphyton, Rotifera, Cladocera (individuals and ephippial eggs) and Copepoda (Tab. I). The algae consumed by $C$. decemmaculatus included Chlorophyta (Ankistrodesmus, Cladophora, Scenedesmus and Phacotus), Bacillariophyta (Aulacoseira, Cyclotella, Epithemia, Gomphonema, Nitzchia and Synedra) and Cyanophyta (Gomphosphaerea, Merismopedia, Microcystis and Planktothrix). According to the alimentary importance index (AII), detritus, phytoplankton, zooplankton (cladocerans, copepods, rotifers) and periphyton were the most important items in the diet (Fig. 2). When each size class is considered separately, the detritus AII mean value increased with fish size (Tab. II), with significant differences between class I and class II $(U=971, p<0.05)$, and between class I and class III (U=452, $\mathrm{p}<0.01)$. Alimentary importance index values of phytoplankton was higher for class II and class III (Tab. II), showing significant differences between class I and class II

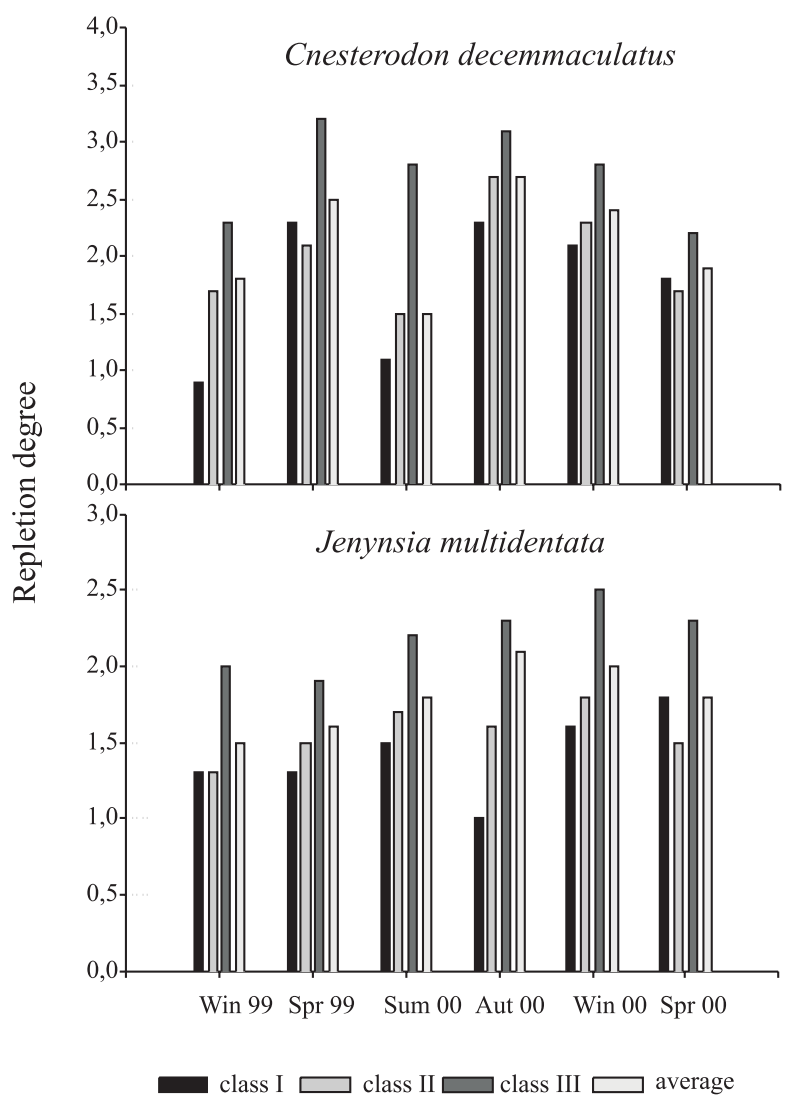

Fig. 1. Repletion index for Cnesterodon decemmaculatus (Jenyns, 1842) and Jenynsia multidentata (Jenyns, 1842) in Rodó Lake from July 1999 to September 2000. 
$(\mathrm{U}=1008, \mathrm{p}<0.05)$. Cladocera and Copepoda were consumed by all size classes mostly during winter 1999 , while class I showed in general higher AII values for Cladocera than other classes during all the sampling periods. Ephippial eggs were found in all samplings except for winter 2000 (Fig. 2), and showed high correlation with Cladocera $(\mathrm{R}=0.898, \mathrm{p}=0.01)$. Rotifera was an important item consumed during summer and winter 2000 samplings by all size classes.

Jenynsia multidentata. In this species $6.3 \%$ of the guts were empty. The mean values of repletion degree showed no significant differences between the morning (1.7), and the evening (1.9) samples. In the temporal scale, the repletion degree values showed lower variability than C. decemmaculatus, being similar between the samplings, principally for the higher body size classes, while the smallest class fish sampled showed a minimum during the autumn 2000 sampling (Fig. 1). In a general form, the repletion degree values tended to be lower than $C$. decemmaculatus ones. As for that species, the RI tended to increase with body size. Mean repletion degree values of classes I, II, and III including all samplings, were 1.4, 1.5 and 2.2 respectively.

According to the frequency of occurrence, the food items most consumed were Copepoda, Cladocera (ephippial eggs and individuals), algae (periphyton), Ephydridae, Diptera (Culicidae) and Hymenoptera (Formicidae) (Tab. I). According to the mean AII values across all samplings, no item could be considered as principal food. Copepoda (0.28), Ephydridae (0.12), Culicidae (0.11), periphyton (0.10), Formicidae (0.09), Cladocera (0.08), Amphipoda (0.07) and Hemiptera (0.06) were the most important items in the diet of $J$. multidentata. With respect to zooplankton, fish from 1999

Table I. Frequency of occurrence (\%) of food items found in the gut contents of Cnesterodon decemmaculatus (Jenyns, 1842) and Jenynsia multidentata (Jenyns, 1842) in Rodó Lake from July 1999 to September 2000.

\begin{tabular}{|c|c|c|c|c|c|c|c|c|c|c|c|c|c|c|}
\hline \multirow[b]{2}{*}{ ITEMS } & \multicolumn{7}{|c|}{ Cnesterodon decemmaculatus } & \multicolumn{6}{|c|}{ Jenynsia multidentata } & \multirow[b]{2}{*}{ Mean } \\
\hline & $\begin{array}{c}\text { Win } \\
99\end{array}$ & $\begin{array}{c}\text { Spr } \\
99\end{array}$ & $\begin{array}{c}\text { Sum } \\
00\end{array}$ & $\begin{array}{c}\text { Aut } \\
00\end{array}$ & $\begin{array}{c}\text { Win } \\
00\end{array}$ & $\begin{array}{c}\text { Spr } \\
00\end{array}$ & Mean & $\begin{array}{c}\text { Win } \\
99\end{array}$ & $\begin{array}{l}\text { Spr } \\
99\end{array}$ & $\begin{array}{c}\text { Sum } \\
00\end{array}$ & $\begin{array}{c}\text { Aut } \\
00\end{array}$ & $\begin{array}{c}\text { Win } \\
00\end{array}$ & $\begin{array}{c}\text { Spr } \\
00\end{array}$ & \\
\hline \multicolumn{15}{|l|}{ Crustacea } \\
\hline \multicolumn{15}{|l|}{ Cladocera } \\
\hline individuals & 68 & 25 & & 3 & 5 & 16 & 27 & 58 & 57 & 3 & & & 6 & 23 \\
\hline ephippial eggs & 63 & 35 & $<1$ & $<1$ & & $<1$ & 24 & 59 & 80 & 3 & & & & 28 \\
\hline Copepoda & 41 & 20 & 24 & 8 & 25 & 23 & 26 & 79 & 26 & 43 & 10 & 60 & 6 & 44 \\
\hline Isopoda & & & & & & & & & & & 3 & & & $<1$ \\
\hline Amphipoda & & & & & & & & 4 & 51 & & & & 3 & 9 \\
\hline \multicolumn{15}{|l|}{ Decapoda } \\
\hline P. argentinus & & & & & & & & & & & 5 & 3 & 3 & 2 \\
\hline Rotifera & 35 & 33 & 89 & 90 & 12 & 5 & 42 & 1 & & 10 & & & & 2 \\
\hline \multicolumn{15}{|l|}{ Insecta } \\
\hline Orthoptera & & & & & & & & 1 & 9 & & 13 & 8 & 18 & 7 \\
\hline Homoptera & & & & & & & & 6 & 14 & & 8 & 8 & 45 & 12 \\
\hline Coleoptera & & & & & & & & 4 & 17 & 3 & 15 & 18 & 6 & 10 \\
\hline \multicolumn{15}{|l|}{ Diptera } \\
\hline \multicolumn{15}{|l|}{ Nematocera } \\
\hline Culicidae & & & & & & & & 3 & 3 & 23 & 18 & 28 & 30 & 16 \\
\hline \multicolumn{15}{|l|}{ Chironomidae } \\
\hline adults & & & & & & & & 45 & 37 & & & & & 18 \\
\hline larvae & 4 & 18 & 3 & 3 & 3 & 3 & 5 & 11 & 12 & 8 & 18 & 8 & & 9 \\
\hline Ephydridae & & & & & & & & 30 & 17 & 3 & 25 & 13 & 57 & 22 \\
\hline \multicolumn{15}{|l|}{ Hymenoptera } \\
\hline Formicidae & & & & & & & & & & 18 & 36 & 40 & 9 & 16 \\
\hline Vespidae & & & & & & & & 26 & 12 & 10 & 22 & 32 & 13 & 19 \\
\hline Collembola & & & & & & & & & 3 & 2 & & & & $<1$ \\
\hline \multicolumn{15}{|l|}{ Arachnida } \\
\hline Araneae & & & & & & & & 1 & & & 10 & 5 & 12 & 4 \\
\hline Acari & & & & & & & & & & & 5 & 2 & & 1 \\
\hline \multicolumn{15}{|l|}{ Pisces } \\
\hline C. decemmaculat & & & & & & & & & & 11 & 5 & 5 & & 3 \\
\hline \multicolumn{15}{|l|}{ Algae } \\
\hline Periphyton & 61 & 70 & 48 & 55 & 97 & 35 & 62 & 11 & 9 & 24 & 43 & 30 & 18 & 22 \\
\hline Phytoplankton & 55 & 80 & 81 & 95 & 100 & 83 & 78 & & & & 7 & & & 1 \\
\hline vegetal material & 21 & 23 & 13 & 28 & 22 & 14 & 20 & & & 10 & 5 & 3 & & 4 \\
\hline detritus & 65 & 78 & 57 & 58 & 100 & 76 & 71 & & & 7 & & & & 1 \\
\hline \multicolumn{3}{|c|}{$\mathrm{N}^{\circ}$ of stomachs analysed } & 278 & & & & & & & & 259 & & & \\
\hline
\end{tabular}


samplings showed high AII values for Copepoda in general and Cladocera (Fig. 3). Body size class I consumed some of the zooplankton components, but principally Copepoda, during all the samplings period, nevertheless on spring 2000 samples it was not relevant. The AII mean value was higher for this class (Tab. II), showing significant differences between all classes (class I and class II: $\mathrm{U}=1152, \mathrm{p}=0.03$, class I and class III: $\mathrm{U}=243$, $\mathrm{p}<0.05$, class II and class III: $\mathrm{U}=861, \mathrm{p}=0.01)$. Copepoda were less abundant in the gut contents of larger fish (Tab. II), being absent on three of the sampling occasions (Fig. $3)$. Periphyton AII mean values were higher for medium and large fish size (Tab. II), showing significant differences between class I and class II $(\mathrm{U}=1172, \mathrm{p}=0.04)$, and between class I and class III ( $U=316, p=0.01)$. Rotifera was not an important item for this species. Amphipoda was important for higher body size classes on both spring samples and only for class 3 on winter 2000 samples. Insects in general were important items during winter and spring 2000, being mostly consumed by higher body size classes of fish sampled. Algae were an item only important on autumn and winter 2000 samples and principally for higher classes. Body size class 3 was the only one that consumed Decapoda items, being their IIA values important only during spring 2000. Pisces was consumed also only by class 3 and only during summer and winter 2000 samplings. This size class was also the only one that showed important IIA values of vegetal material and only for summer 2000 and in a less sense autumn 2000, being the first the higher.

Feeding overlap. The feeding overlap between both species, considering all size classes was 0.25 . The $\mathrm{C}$ values between each size class were generally low. The highest value was observed for class I of both species (Tab. III).

For $C$. decemmaculatus the three fish size classes analysed showed high feeding overlap. The highest $\mathrm{C}$ value was observed between class II and class III (0.99), followed by the value between class I and class II (0.89) and class I and class III (0.86). The highest feeding overlap value for $J$. multidentata was observed between class I and class II (0.87); the $\mathrm{C}$ value between class II and class III was 0.51 and between class I and class III was 0.44 (Tab. IV).

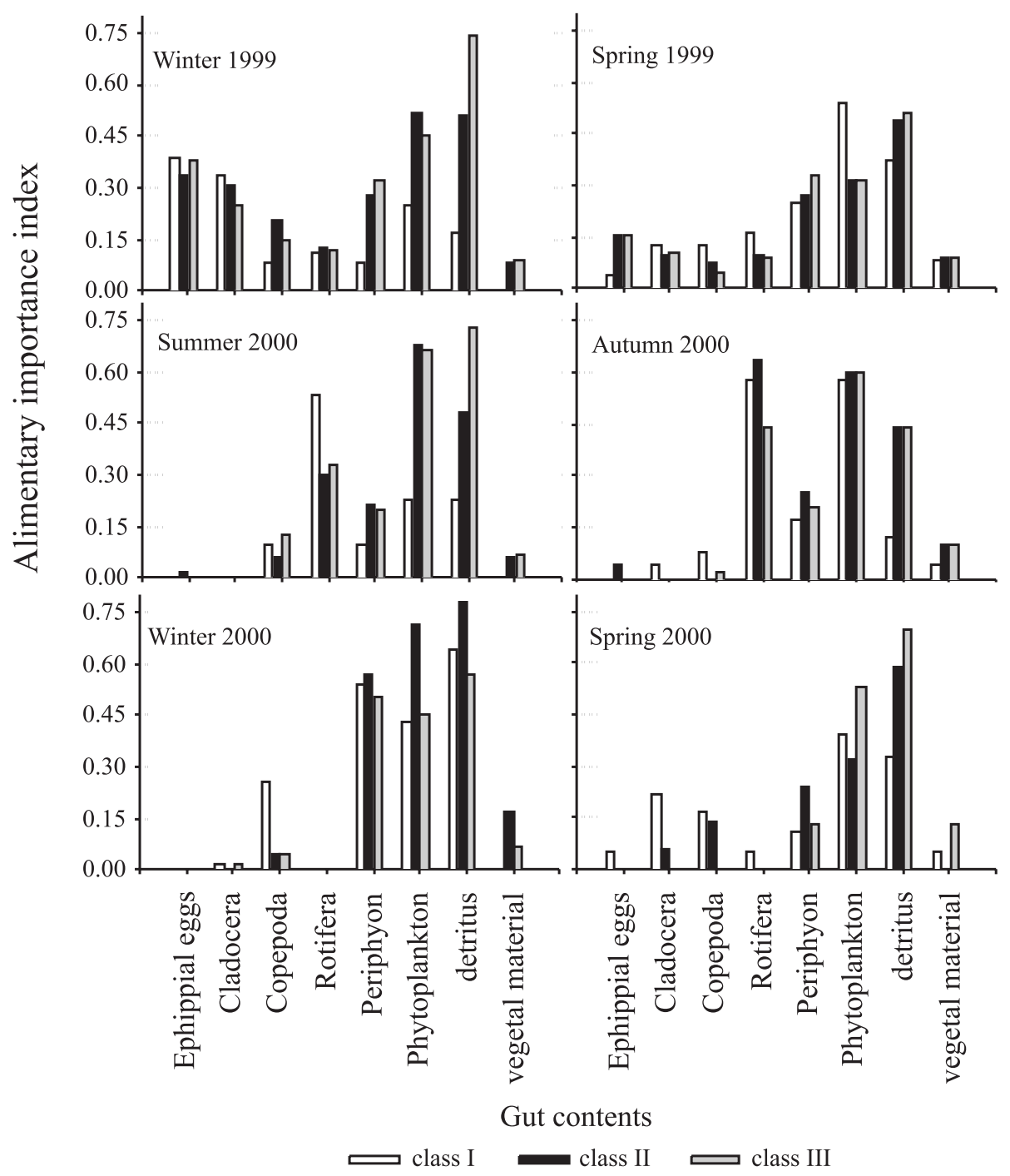

Fig. 2. Alimentary importance index for the main items consumed by Cnesterodon decemmaculatus (Jenyns, 1842) in Rodó Lake from July 1999 to September 2000. 
Table II. Alimentary importance index means values of the most important items for the three size classes of Cnesterodon decemmaculatus (Jenyns, 1842) and Jenynsia multidentata (Jenyns, 1842) in Rodó Lake from July 1999 to September 2000.

\begin{tabular}{llllllll}
\hline & \multicolumn{3}{c}{ C. decemmaculatus } & \multicolumn{3}{c}{$J}$. & multidentata \\
ITEM & class I & class II & class III class I & class II & class III \\
\hline Detritus & 0.31 & 0.55 & 0.62 & & 0.01 & 0.04 \\
Phytoplankton & 0.40 & 0.52 & 0.50 & & & \\
Periphyton & 0.21 & 0.30 & 0.28 & 0.07 & 0.16 & 0.19 \\
Cladocera & 0.12 & 0.08 & 0.06 & 0.10 & 0.09 & 0.07 \\
Copepoda & 0.28 & 0.09 & 0.07 & 0.47 & 0.29 & 0.06 \\
Rotifera & 0.24 & 0.19 & 0.26 & 0.01 & 0.01 & 0.01 \\
Ephydridae & & & & 0.08 & 0.12 & 0.16 \\
Culicidae & & & & 0.15 & 0.13 & 0.06 \\
Formicidae & & & & 0.10 & 0.10 & 0.07 \\
Homoptera & & & & 0.10 & 0.06 & 0.03 \\
Amphipoda & & & & & 0.08 & 0.13 \\
\hline
\end{tabular}

Table III. Feeding overlap between Cnesterodon decemmaculatus (Jenyns, 1842) and Jenynsia multidentata (Jenyns, 1842) in Rodó Lake from July 1999 to September 2000.

\begin{tabular}{lccc}
\hline & \multicolumn{3}{c}{$J$. multidentata } \\
C. decemmaculatus & class I & class II & class III \\
class I & 0.44 & 0.21 & 0.25 \\
class II & 0.03 & 0.09 & 0.11 \\
class III & 0.23 & 0.03 & 0.11 \\
\hline
\end{tabular}

Table IV. Feeding overlap on Cnesterodon decemmaculatus (Jenyns, 1842) and Jenynsia multidentata (Jenyns, 1842) in Rodó Lake from July 1999 to September 2000.

\begin{tabular}{lcccc}
\hline & \multicolumn{2}{c}{ C. decemmaculatus } & \multicolumn{2}{c}{ J. multidentata } \\
& class II & class III & class II & class III \\
class I & 0.89 & 0.86 & 0.87 & 0.44 \\
class II & & 0.99 & & 0.51 \\
\hline
\end{tabular}

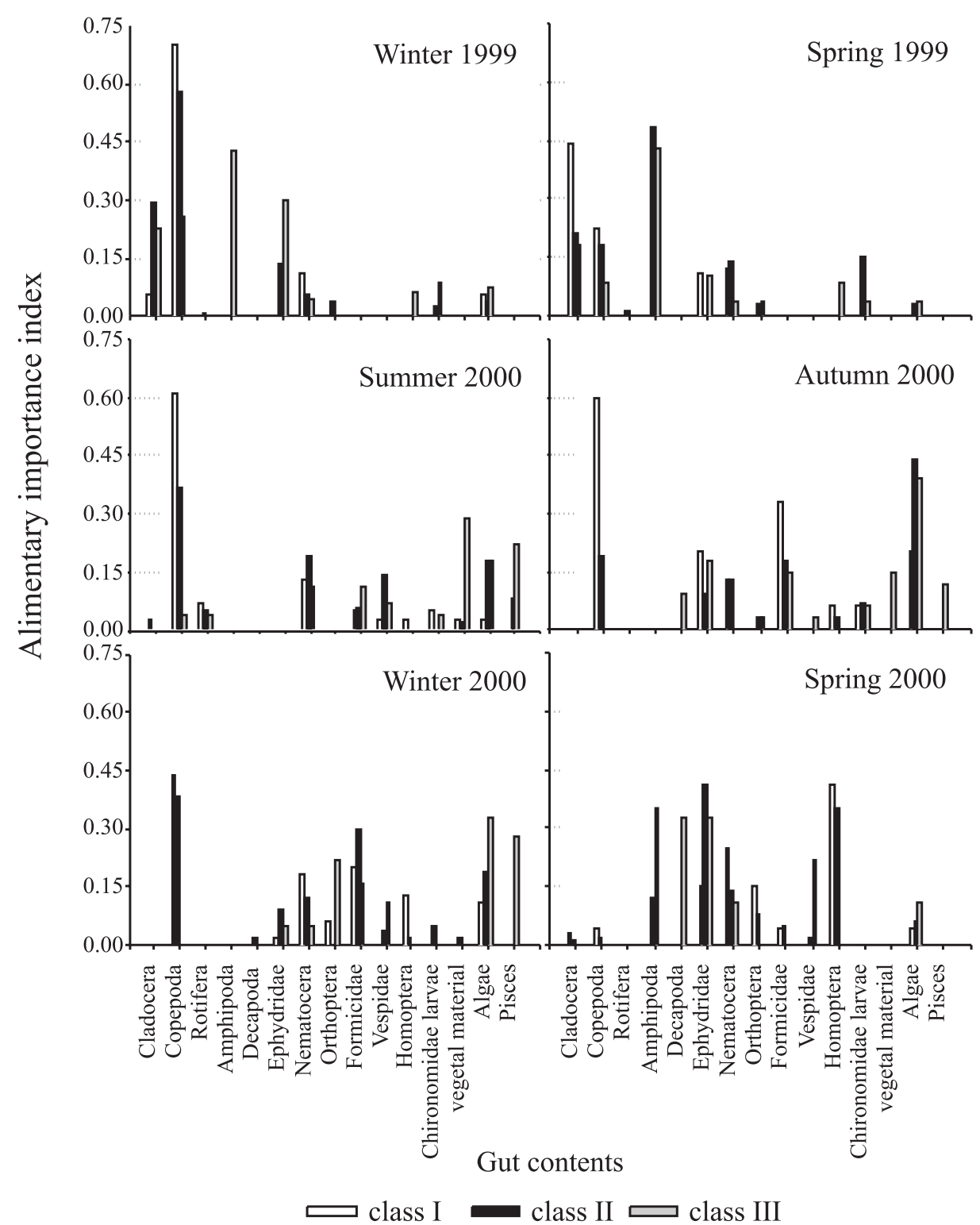

Fig. 3. Alimentary importance index for the main items consumed by Jenynsia multidentata (Jenyns, 1842) in Rodó Lake from July 1999 to September 2000. 


\section{DISCUSSION}

Both species analyzed in this study displayed an omnivorous diet, being zooplankton, Chironomidae larvae, periphyton, and phytoplankton the items shared in their diets. The mean RI showed a tendency to increase it values with body size. Higher body size classes of $C$. decemmaculatus tended to feed relatively more on detritus and phytoplankton, and these items contributed to increase the RI, especially when zooplankton items showed lower AII values.

The smallest body size class showed the lowest RI values during winter 1999 and summer 2000, when zooplankton items were important in its diet (Cladocera and Copepoda in winter, and Rotifera in summer). This size class showed higher RI values when detritus and phytoplankton were important items in its diet. This could be explained because zooplankton items, mainly Cladocera and Copepoda, would satisfy their energetic requirements in a more efficient way. Thus, when zooplancton is consumed, fish do not need to feed large quantities of items less nutritive, as phytoplankton and detritus. MiCHELSEN et al. (1994) observed that, in a Swedish lake, two fish species completed their energetic requirements feeding on detritus during low abundance of food from animal source. In the case of $J$. multidentata we observed that Copepoda (mainly smaller size classes) and Amphipoda and Algae (higher size classes) were important items in the diet during samplings periods when other items were present at lower AII values. In this sense, this species, particularly the higher body size classes, could alternate between insects and crustaceans depending on their availability in the environment. When all items are present, fish consume them simultaneously.

Smaller individuals of both species had a high dietary overlap because they consume proportionally more zooplankton, than larger individuals. As fish became bigger, zooplankton showed a decrease in their diets, while periphyton consumption increased. Ontogenetic change in diet is a common tendency in fish, since there is a direct relationship between mouth gape and prey size (GumA'A, 1978). Consequently, as fish grow they tend to feed progressively upon larger prey (Mills et al., 1985; LAZZARO, 1987). In this sense, an increase in the consumption of detritus and algae in higher body size class of $C$. decemmaculatus could be due to the unavailability of adequate size preys.

On the other hand, medium size class individuals of $J$. multidentata fed mainly on terrestrial insects; while amphipods, shrimps and small fish were also important in the diet of largest. Therefore, while the $C$. decemmaculatus population of the lake strongly depends on the organic matter of the sediments and primary producers, J. multidentata take advantage of pleuston and small invertebrates associated to macrophytes. The lowest feeding overlap values observed for the different size classes of J. multidentata suggest a major ontogenetic diet change for this species.

Ephippial eggs can be obtained indirectly by eating cladoceran adults or directly by taking them from the sediment. LAZZARo (1987) found that ephippial eggs increase cladocerans vulnerability to fish visual predation. The high correlation between Cladocera and ephippials in the gut contents of $C$. decemmaculatus, support that view.

Generally, fish diet has a strong relationship with food availability (GERKING, 1994). The availability of some of the items consumed by these species in Lake Rodó is variable throughout the year. Periphyton, detritus and phytoplankton are available the whole year, while zooplankton (specially Cladocera) shows high seasonal variability (ScASSO et al., 2001). This could explain the absence of this item in the diet of both species during some periods of the year. In this sense, the almost absence of Cladocera in the diet on summer 2000 fish samples is concordant with the extremely low abundance of this group in the lake at that moment (MeERHOFF et al., 2003). However, their consumption should be important when they are abundant in the lake.

Facultative planktivores are opportunistic feeders, switching to food sources other than plankton like suspended organic particles, periphyton, macrophytes, insects or benthic animals and plants, when zooplankton is less available (LAZZARO, 1987). Our results suggest that C. decemmaculatus and J. multidentata could be acting as facultative planktivores in Lake Rodó. The diminishing of large-bodied herbivorous zooplankton caused by fish predation favours the increment of phytoplankton (Brooks \& Dodson, 1965; Hutchinson, 1971; SHAPIRO \& Wright, 1984; Post \& Mc QueEn, 1987). Experiments in mesocosms showed that Gambusia affinis (Baird \& Girard, 1853), a small Poeciliid from southern North America, phylogenetically related and morphologically similar species to $C$. decemmaculatus, caused the reduction of large-bodied zooplankton and favoured the development of persistent high-density algal bloom (Hurlbert et al., 1972; Hurlbert \& Mulla, 1981).

Although cascade effects of fish predation on trophic webs in lakes can be less evident when omnivorous fish are dominant, abundant populations of small omnivorous fish are thought to maintain a high predation pressure on zooplankton, leading to the absence of large-bodied herbivores (LAZZARO, 1997). This is a common situation of several degraded ecosystems of Uruguay, where the populations of C. decemmaculatus and $J$. multidentata often dominate fish communities (SCASSO et al., 2001; MAZZEO et al., 2003). Cnesterodon decemmaculatus is one of the most tolerant fish to water quality degradation in the region (BISTONI et al., 1999). Thus, in eutrophic and polluted ecosystems the absence of predators generates high-density populations (SCASSO et al., 2001). In Lake Rodó the maximum density of $C$. decemmaculatus was 97,000 ind. ha ${ }^{-1}$ (SCAsso et al., 2001). Jenynsia multidentata populations can also be very abundant in stressed ecosystems of the region, raising as much as 130,000 ind ha ${ }^{-1}$ in a small coastal lake (MAZZEO et al., 2003).

We suggest that in environments where fish community is dominated by these species and they are particularly abundant, predation pressure on large-bodied zooplankton could be excessive, diminishing considerably their abundance and thus indirectly contributing to maintain a high phytoplankton biomass, diminishing water transparency. 
Acknowledgments. We thank M. Martínez, J. Clemente, C. Kruk, G. Lacerot, D. McKee, X. Lazzaro, S. Hartz, M. Meerhoff and F. García-Rodriguez for their help in the identification of prey items and comments on improving the manuscript. This work was partially funded by the Municipality of Montevideo.

\section{REFERENCES}

Albertine-Berhaut, J. A. 1973. Biologie des stades juveniles des téleostéens Mugilidae Mugil auratus Risso 1810, Mugil capito Cuvier 1829 et Mugil saliens (Risso 1810): I. Régime alimentaire. Aquaculture 2:251-266.

Bistoni, M. A.; Hued, A.; Videla, M. \& Sagretti, L. 1999. Water quality effects on fish communities of the central part of Argentina. Revista Chilena de Historia Natural 72:325-335.

Brooks, J. L. \& Dodson, S. I. 1965. Predation, body size and composition of plankton. Science 150:28-35.

Escalante, A. 1983. Contribución al conocimiento de las relaciones tróficas de peces de agua dulce del área Platense. III. Otras especies. Limnibios 2:453-463.

Gerking, S. D. 1994. Feeding Ecology of Fish. San Diego, Academic. $416 \mathrm{p}$.

Ghedotti, M. J. 1998. Phylogeny and classification of the Anablepidae (Teleostei: Cyprinodontiformes). In: Malabarba, L. R.; Reis, R. E.; Vari, R. P.; Lucena, Z. M. S. \& Lucena, C. A. S. eds. Phylogeny and Classification of Neotropical Fishes. Porto Alegre, Edipucrs. p.561-582.

Granado, C. \& García-Novo, F. 1986. Feeding habitats of the fish community in a eutrophic reservoir in Spain. Ekologia Polska 34:95-110.

Guillén, G. \& Granado, C. 1984. Alimentación de la ictiofauna del embalse de Torrejón (Río Tajo, Cáceres). Limnética 1:304-310.

GumA'A, S. A. 1978. The food and feeding habits of young perch, Perca fluviatilis, in Windermere. Freshwater Biology 8:177-187.

HoRn, H. S. 1966. Measure of "overlap" in comparative ecological studies. American Naturalist 100:419-424.

Hurlbert, S. H. \& Mulla, M. 1981. Impact of mosquitofish (Gambusia affinis) predation on plankton communities. Hydrobiologia 83:125-151.

Hurlbert, S. H.; Zedler, J. \& Fairbanks, D. 1972. Ecosystem alteration by mosquitofish (Gambusia affinis) predation. Science 175:639-641.

Hutchinson, B. P. 1971. The effect of fish predation on the zooplankton of ten Adirondak Lakes, with particular reference to the alewife Alosa pseudoharengus. Transactions of the American Fisheries Society 110:325-335.

Hyslop, E. J. 1980. Stomach contents analysis - A review of methods and their application. Journal of Fish Biology 17:411-429.

Johansson, L. \& Persson, L. 1986. The fish community of temperate eutrophic lakes. In: Riemann, B. \& SondegaArd, M. eds. Carbon dynamics in eutrophic, temperate lakes. Amsterdam, Elsevier Science. p.237-266.

Krebs, C. J. 1989. Ecological metodology. New York, Harper \& Row. 654p.
Lazzaro, X. 1987. A review of planktivorous fishes: Their evolution, feeding, behaviours, selectivities and impacts. Hydrobiologia 146:96-167.

1997. Do the trophic cascade hypothesis and classical biomanipulation approaches apply to tropical lakes and reservoirs? Verhandlungen der Internationalen Vereinigung für Theoretische und Angewandte Limnologie 26:719-730.

Mazzeo, N.; Rodríguez-Gallego, L.; KruK, C.; Meerhoff, M.; Gorga, J.; Lacerot, G.; Quintans, F.; Loureiro, M.; Larrea, D. \& García-Rodríguez, F. 2003. Effects of Egeria densa Planch. beds on a shallow lake without poscivorous fish. Hydrobiologia 506-609:591-602.

Mc QueEn, D. J. 1990. Manipulating lake community structure: where do we go from here? Freshwater Biology 23:613-620.

Meerhoff, M.; Mazzeo, N.; Moss, B. \& Rodríguez-Gallego, L. 2003. The structuring role of free-floating versus submerged plants in a subtropical shallow lake. Aquatic Ecology 37:377-391.

Michelsen, K.; Pedersen, J; Christoffersen, K. \& Jensen, F. 1994. Ecological consequences of food partitioning for the fish population structure in a eutrophic lake. Hydrobiologia 291:35-45

Mills, C. A.; Behaumont, W. R. C. \& Clarke, R. T. 1985. Sources of variation in the feeding of larval dace Leucicus leuciscus in an english river. Transactions of the American Fisheries Society 114:519-524.

Persson, L.; Andersson, S.; Harmin, F. \& Johansson, L. 1988. Predator regulation and primary production along the productivity gradient at temperate lake ecosystem. In: Carpenter, S. R. ed. Complex interactions in lake communities. New York, Springer Verlag. p.45-65.

Pinel-Alloul, B.; Mazumder, A.; Lacroix, G. \& Lazzaro, X. 1998. Lake trophic food webs: structure, function, interactions and spatio-temporal variations. Revue des Sciences de l'Eau no special:163-197.

Post, J. R. \& Mc QueEn, D. J. 1987. The impact of planktivorous fish on the structure of a plankton community. Freshwater Biology 17:79-89.

Rosa, R. S. \& Costa, W. J. E. M. 1993. Systematic revision of the genus Cnesterodon (Cyprinodontiformes: Poecilidae) with the description of two new species from Brazil. Copeia 3:696-708.

Scasso, F.; Mazzeo, N.; Gorga, J.; Kruk, C.; Lacerot, G.; Clemente, J.; Fabián, D. \& Bonilla, S. 2001. Limnological changes of a subtropical shallow hypertrophic lake during its restoration. Two years of whole-lake experiment. Aquatic Conservation: Marine Freshwater Ecosystems 11:31-44.

Shapiro, J. \& Wright, D. I. 1984. Lake restoration by biomanipulation: Round Lake, Minnesota, the first two years. Freshwater Biology 14:371-383.

ZAR, J. H. 1999. Biostatistical analysis. New Jersey, Prentice Hall. 663p

Zaret, T. M. \& RAND, A. S. 1971. Competition in tropical stream fishes: support for the competitive exclusion principle. Ecology 52(2):336-342. 